\title{
AC 2007-367: FOSTERING MORAL AUTONOMY OF FUTURE ENGINEERS THROUGH ENGINEERING CLASSROOMS
}

\section{June Marshall, St. Joseph's College}

JUNE MARSHALL received her doctorate from North Carolina State University and is a tenured faculty member at St. Joseph's College in Maine. Her specialization is learning strategies focusing specifically in cooperative leaning and character education.

\section{John Marshall, University of Southern Maine}

JOHN MARSHALL received his Ph.D. from Texas A\&M University and is the Internship Coordinator for the University of Southern Maine's Department of Technology. His areas of specialization include Power and Energy Processing, Electronic Control Systems, and Automation. 


\title{
Fostering Moral Autonomy of Future Engineers Through Engineering Classrooms
}

\begin{abstract}
The goal of engineering ethics instruction according to Fleddermann is to help future engineers develop "the ability to think critically and independently about moral issues and to apply this moral thinking...to professional engineering practice". ${ }^{3}$ In order to develop this independent approach or moral autonomy, engineering programs across the nation should consider the individuals' emerging personal code of ethics and the role their campus integrity policies could play in fostering the individuals' emerging personal code of ethics.
\end{abstract}

This presentation focuses on how to provide a learning continuum where student's can reflect, mentor each other and provide opportunities to share their emerging moral autonomy. Successful techniques are presented that have been proven to be very useful in providing this required instruction to future professionals.

Introduction

Character without knowledge is weak and feeble, but knowledge without character is dangerous and a potential menace to society. Character and knowledge together are the twin goals of true education.

Boston Latin Grammar School, $17^{\text {th }}$ century ${ }^{1}$

All engineering curriculums are now required to implement the ABET Code of Ethics as defined in the "Engineering Criteria 2000" 2 document. In implementing this code Gee cautions that, "blind devotion to ethical codes will not address the ethical concerns of the engineering profession. The study of engineering ethics must therefore begin with the study of personal values. The final burden is upon the individual's conscience and values." "Engineering ethics curriculums should emphasize that all decisions-both professional and personal-are based on one's values. No one makes decisions of any kind in a moral vacuum; no decision is value-free. Beginning professionals need to be made aware of this reality, as it is germane to developing professional integrity. When individuals have had the opportunity to explore and develop their own moral autonomy, this moral framework then serves as an explicit roadmap for any decision they make.

Fleddermann in Engineering Ethics cites that the goal of engineering ethics can be summed up in the term "moral autonomy". ${ }^{3}$ He defines moral autonomy as the ability of the professional to think critically and independently about moral issues and to apply this moral thinking to situations that arise in professional engineering practice. 
Engineering programs across the nation continue to investigate classroom techniques regarding ethics instruction. Lewis suggests, "professional ethics are molded and shaped by three identifiable attributes". 8 The first attribute involves the development of the moral individual, the second is the influence the profession has on the individual and the third involves the standards that govern ethical conduct which have been developed by the professional society.

This emphasis in ethics education is not limited to the engineering profession alone. In fact, this is a component of a much more global movement whose roots lie in behavioral ethics, and can be viewed as an understanding of desirable and undesirable actions based on a society's perceptions and norms. Once an individual understands and perceives society's distinctions between positive and negative actions, ethics education then enables the individual to internalize these values. As a result, the individual develops a personal code of professional conduct, which then guides his/her daily interaction.

The professional code cannot be developed before the personal code. The question then remains, how do Engineering curriculums develop appropriate learning experiences to facilitate the development of personal codes that will positively impact the professional code?

\section{The Call for Ethics Education for American Professionals}

Historically, Dewey believed that moral education could not be divorced from the school curriculum. Rather, it should be delivered through all of the "agencies, instrumentalities, and materials of school life". 1 Ryan suggested that "the morals, values and ethics we want students to learn should be identified by adults and taught by matching the topic and level of intensity to the students' developmental level". ${ }^{10}$ Direct teaching of these preselected morals aims at the transmission, acquisition and exercise of what are seen as the accepted moral values of the culture (such as honesty and responsibility), and "emphasizes the principles of learning and social learning theory". 11

Whitbeck agrees that "rather than simply studying a code, a more engaging active learning approach" 13 is needed. Evidence has shown that the introduction of engineering ethics as a significant theme in the curriculum provides distinctive added value. This theme contributes to other learning outcomes by helping students to improve core skills such as communication, reasoning, deduction, and reflection.

The pedagogic function should be on developing skills and judgments as well as providing exposure to ethical concepts and ideas. The Teaching of Engineering Ethics Working Group believes that students should be able to recognize the various problems and pitfalls that emerge unexpectedly in real human engagement, and be able to adopt sound and morally defensible responses at the time of the engagement. To help students achieve this coursework where one of the major goals is an opportunity to explore one's own values in ethical issues remains critical. 


\section{Developing an Ethics Education Component}

Within our program, future professionals begin their classroom ethics discussions with an introduction to the college's adopted academic integrity policy. This policy incorporates a set of core values. These values form the basis of the policy and include: excellence, integrity, community, respect, compassion, and justice. Students must clarify for themselves where they personally stand on these issues. In classes we want them to begin investigating the morals, ethics, and values that support their sense of personal self, understand how these terms are presently being defined, and be introduced to real-life scenarios where ethics must be incorporated.

In the introductory ethics course students actually walk over to the student center and view the core values which are painted on the wall. Discussions of these values begin with personal definitions and examples of instances where these values affected outcomes in the students' lives. Definitions of the values, as per the college catalog, are then incorporated into the discussions. Students then engage in small group and class discussions surrounding real world ethical scenarios including issues such as: the right to protect endangered spotted owls in old growth forests of the northwest-and the right to provide jobs for loggers, the right to provide our children with the finest public schools available-and the right to prevent the constant increase of state and local taxes, the right to refrain from interfering in the internal affairs of sovereign nations-and the right to help protect the innocent in regions where they are subject to slaughter. These case studies provide opportunities for students to perform ethical analysis of social and personal ethics in action.

The next step is to introduce the three principles for resolving dilemmas according to the Institute for Global Ethics. These three principles grow out of everyday human experience and are widely used as the reasoning implemented in resolving tough ethical issues.

- Do what's best for the greatest number of people (ends-based).

- Follow your highest sense of principle (rule-based).

- Do what you want others to do to you (care-based). ${ }^{5}$

Kidder points out that each of the principles has a long history in moral philosophy or religious instruction and that they have worked their way into the teaching and practice of ethics because each is an inherent element of human thought. In addition to these three principles, ethics also inherently includes the concept of "ought." Often it is not about what you do because of requirements (like paying for your cup of coffee) it is about what you "ought" to do-because it is "right." 6

Many of the ethical dilemmas that we face today are actually right-versus-right dilemmas. These dilemmas arise not because we lack values but because both parties involved have values, two of which are pitted against each other. It is not merely enough to recognize 
that right-versus-right dilemmas are difficult to resolve or that they can be approached and analyzed in an organized manner. Teachers must provide a problem solving model that can be consistently applied for resolution.

Do what's best for the greatest good reflects the ends-based philosophy. This approach is a form of consequentialism because when we attempt to determine the greatest good we are also guessing at what the future consequences might be. Rule-based thinking centers on what will happen if everyone in the world follows the rule I am about to apply? This train of thought challenges the idea that we can never know what the outcomes of our actions will be; however we believe that we must follow our principles and let things happen as they may. The Golden Rule or care-based principle asks us to put ourselves in another's shoes. Also called the rule of reversibility, it calls us to imagine how the recipient will react as a result of our actions.

Case studies highlighting the implementation of this process are analyzed in small groups. One case study (Kidder \& Born) utilized with great success springs from the classroom arena. A brief synopsis of the case study is presented here for discussion purposes.

A teacher in a rural school with limited resources had a bright, well-meaning and engaging child in her classroom. The student however had very limited social skills which became extremely apparent when he was asked to work cooperatively in a group. Within a group structure, the boy became willful and manipulative. The teacher observed as time went on, that whatever team he was assigned to got into difficulties, lost focus, and never completed their objectives. Groups were beginning to avoid him and tensions in the classroom were increasing. In spite of this rebellion, he was actually making slow but positive progress in learning to work with others.

The dilemma centered on whether the teacher should continue to allow him to participate even though the group suffered? Or should the teacher remove him from the cooperative learning activities so that all the groups could progress faster? One might point to this example and classify it as a pedagogical challenge that could be resolved through educational psychology, behavior theory, or teacher traditions. Yet what this teacher faced "is a classic ethical dilemma-amenable to resolution not so much through competing theories of learning as through the principles of moral philosophy". ${ }^{7}$ It is a right-versusright dilemma.

Students in the college-level ethics course are then asked to consider how the three principles might apply to this dilemma:

- The ends-based principle concedes that because the behavior is detrimental to the group's achievement he should be banned from group work until he learns to cooperate.

- The rule-based principle encourages the teacher to ask what if every teacher in the world were to do what I am planning to do and would they always allow he to 
participate or never allow him to participate? There is only one standard and it would be tough to decide that all students like him would never be allowed to participate.

- The care-based principle requires that the teacher identify the "others". The student is important, but so are the classmates. By including him the teacher demonstrates the care principle but what are the consequences for the others? Is there a possible alternative?

Throughout the process of applying the model it becomes clear that there is no easy solution. However, the model allows the teacher to operationalize the language of ethical decision making and has learned a powerful tool that can be used throughout her professional practice. What happened in this real-life scenario? The teacher requested that the student visit the special education classroom during the cooperative learning activities. She felt that her responsibility was to provide a positive and successful classroom environment for the rest of her students. In the classroom, educators must model a balanced, reasoned process concerning ethical dilemmas. This transfers to students the concept of personal responsibility that will be essential to surviving future challenges.

After several similar real-world scenarios like the example above, have been processed in small groups, class work then moves forward to apply their personal definitions of the core values along with the three principles to engineering case studies. Fleddermann (2004) begins the analysis of ethical problems in engineering by sorting a problem into the three categories of: factual, conceptual, and moral issues. The Paradyne Computer case study highlighted in, Engineering Ethics has been successfully utilized in the classroom. A synopsis with analysis is offered here for example purposes:

The Paradyne Computer Company put in a bid to supply the Social Security Administration (SSA) with new computer systems. The factual issues included that the company intended to implement a new system that had not been tested even though the request was for an existing system. In addition, a Paradyne employee who was a former SSA worker lobbied for the contract.

The conceptual issues centered on the questions of: is it deceptive to place the Paradyne label over the original manufacturers label to present a product as off-the-shelf or is there a conflict of interest when a former employee lobbies for services to advance their current employment?

The moral issues centered on: "is lying an acceptable business practice? Is it alright to be deceptive if doing so allows your company to get the contract?" ${ }^{3}$ Fleddermann concludes that lying and deceit are not acceptable in either your personal life or business life. This type of case study examination provides a rich environment for the continuing development and application of personal and professional ethics. 
Additional examples of personal to professional application of ethics were highlighted in Pfatteicher's article that appeared in the January 2001 edition of the Journal of Engineering Education. In one illustration, students were provided a copy of the NSPE Code of Ethics and sample case studies. "Groups of students were challenged to apply the code to the cases. The groups then compared their results, leading to interesting class discussions that identified different perspectives on the issues. After which, the class's conclusions were compared to the findings of the NSPE Board of Ethical and Professional Responsibility for the actual cases". ${ }^{9}$ This approach leads students to consider the value that engineering ethics has to the profession and the role of personal ethics in these decisions.

Ethical instruction through the core values included in the academic integrity policy provides consistent opportunities over time for students to engage in developing their own code, which in turn provides the foundation for their professional code. The personal understanding, development, and application of the foundational aspects of ethics: excellence, integrity, community, respect, compassion, and justice first to general life experiences enables students to move more seamlessly into ethical application in a professional setting Undergraduate engineering programs must respond to the cultural change that incorporates the value of the person in the productive process of engineering. The engineer must respond to the problems of society with responsibility, demonstrating their moral autonomy through the professional conduct code. The ability to effectively weave these two pieces demands suitable preparation in the undergraduate curriculums.

\section{Conclusion}

Ethics is a component in many professional curriculums across the nation. Some engineering programs are electing to teach specific courses related to this topic, while other programs are investigating techniques to implement this requirement into existing courses. Whitbeck summarizes the objective of the classroom experience:

"The responsibilities of adults as citizens, community members, and professionals are complex and demanding. University education should enable students to integrate ethical understanding of these complex responsibilities with the advanced knowledge that they will draw on in deciding how best to meet those responsibilities". ${ }^{3}$

Lewis in his article The Cultivation of Professional Ethics concludes that the Engineering community has a responsibility to produce individuals "with strong moral fiber, a dedication to professional integrity, and the ability to reason soundly". 8 The professional excellence of the engineer and the commitment of continuous improvement are only possible if solid moral values have consolidated.

Engineering educators need to provide their students with proactive learning opportunities to facilitate the development of moral autonomy. This development needs to be ongoing and responsive to experiences and applications. Requiring students to cast 
judgments while implementing the professional code without opportunities for personal development is a disservice to these young professionals. We, as faculty, must provide the basis for demonstrating ABET's Engineering Criteria 2000 which states that, "engineering programs must demonstrate that their graduates have . . a an understanding of professional and ethical responsibility". ${ }^{2}$

Bibliographic Information

1. Dewey, J. (1909/1975). Moral Principals in Education. Carbondale, IL: Southern Illinois University Press.

2. Engineering Criteria 2000: Criteria for Accrediting Programs in Engineering in the United States." $3^{\text {rd }}$ ed., Engineering Accreditation Commission, Accreditation Board for Engineering and Technology, Inc., Baltimore, MD, Dec., 1997, http://www.abet.org/eac/eac2000.

3. Fleddermann, C. B. (2004). Engineering Ethics. Upper Saddle River, NJ: Pearson Prentice Hall.

4. Gee, E. (2004). Moral Vision and the Landscape of Engineering Professionalism. National Society of Professional Engineers. Retrieved September 20, 2004. http://www.nspe.org/ethics/eh1-vis.asp

5. Institute for Global Ethics (2001). Readings in Ethics. Camden, ME.

6. Kidder, R.M. (1995). How Good People Make Tough Choices: Resolving The Dilemmas of Ethical Living. William Morrow \& Co.

7. Kidder, R.M. \& Born, P.L. (1998-1999). Resolving ethical dilemmas in the classroom. Educational Leadership, 21, 38-41.

8. Lewis, L. (2004). The Cultivation of Professional Ethics. Retrieved September 20, 2004. http://www.nspe.org/ethics/eh 1-lew.asp

9. Pfatteicher, S. (2001). Teaching vs. Preaching: EC200 and the Engineering ethics Dilemma. Journal of Engineering Education, 1, 137-142.

10. Ryan, K., Bohlin, K. (2000). Teacher education's empty suit. Education Week on the WEB. Retrieved March 29, 2000. http://www.edweek.org/ew/ewstory.cfm?slug=26ryan.h19

11. Ryan, K. (1996). Character education in the United States: A status report. Journal for a Just and Caring Education, 2 (1), 75-84.

12. Solomon, D., Watson, M., Battistich, V. (2000). Teaching and school effects on moral/prosocial development. In Handbook of Research on Teaching, $4^{\text {th }}$ Edition (in press).

13. Whitbeck, C. (2004) Onlineethics.org: The Online Ethics Center For Engineering and Science at CASE Western Reserve University. Retrieved January 11, 2004. Onlineethics.org 